\title{
PEMBELAJARAN QTL BERBASIS PROYEK DALAM BENTUK WEB UNTUK MENINGKATKAN MOTIVASI DAN KETERAMPILAN BERPIKIR 4C
}

\author{
Fitriana Eka Chandra ${ }^{1}$, Fury Setyo Siskawati ${ }^{2}$ \\ ${ }^{1}$ Program Studi Pendidikan Matematika FKIP Universitas Khairun \\ ${ }^{2}$ Program Studi Pendidikan Matematika Universitas Islam Jember \\ Email: chanfi90ceca@gmail.com
}

\begin{abstract}
Abstrak:
Selama masa pembelajaran daring diperlukan suatu model pembelajaran yang dapat melatih siswa untuk tetap dapat meningkatkan keterampilan berpikir 4C selama pembelajaran daring. Salah satu pembelajaran yang dapat digunakan untuk menyelesaikan masalah guru dalam era pandemi ini adalah Quantum Teaching and Learning (QTL) yang dapat dikolaborasikan dengan pemberian tugas berupa proyek melalui penyajian dalam bentuk web. Tujuan dari penelitian ini adalah untuk mengkaji lebih jauh bagaimanakah pembelajaran QTL berbasis proyek yang sesuai untuk dikembangkan dalam bentuk web agar dapat meningkatkan motivasi dan keterampilan berpikir 4C siswa. Penelitian ini merupakan penelitian deskriptif berbentuk kajian literatur yang dilakukan dengan mengkaji beberapa literatur. Subjeknya berupa beberapa artikel terkait pembelajaran QTL, pembelajaran berbasis proyek, motivasi dan keterampilan berpikir 4C, dan pembelajaran berbasis web. Dengan metode pengumpulan datanya yaitu dokumentasi dan analisis datanya menggunakan teori Milles dan Hulberman yang meliputi reduksi data, penyajian dan penarikan simpulan. Berdasarkan kajian teori dari beberapa artikel diketahui bahwa pembelajaran QTL dapat meningkatkan motivasi belajar siswa karena QTL diajarkan sesuai dengan alam berpikir siswa. Pemberian proyek yang sesuai dengan minat siswa dapat ditambahkan dalam pembelajaran QTL untuk melatih siswa meningkatkan keterampilan berpikir 4C.
\end{abstract}

Kata Kunci: Quantum Teaching and Learning (QTL), Proyek, WEB, Keterampilan Berpikir 4C

\begin{abstract}
:
During online learning, A learning model is needed that can train students so that students can still practice improving their 4C thinking skills. One of the lessons that can be used to solve teacher problems in this pandemic era is Quantum Teaching and Learning (QTL) learning which can be collaborated with giving assignments in the form of projects through web presentations. The purpose of this study is to further examine how project-based QTL learning is appropriate to be developed in web form in order to increase students' motivation and $4 \mathrm{C}$ thinking skills. This research is a descriptive study in the form of a literature review conducted by reviewing several literatures. The subjects are several articles related to QTL learning, project-based learning, motivation and $4 \mathrm{C}$ thinking skills, and web-based learning. The data collection method is documentation and data analysis using the theory of Milles and Hulberman which includes data reduction, presentation and drawing conclusions. Based on the literature review, it can be seen that one approach that can be used is a project-based Quantum Teaching and Learning (QTL) approach which can be presented in web form so that students are more motivated during the online learning period. Based on theoretical studies from several articles, it is known that learning QTL can increase students' learning motivation because QTL is taught according to students' thinking. Giving projects that are in accordance with students' interests can be added to QTL learning to train students to improve $4 \mathrm{C}$ thinking skills.
\end{abstract}

Keywords: Quantum Teaching and Learning (QTL), Project, WEB, 4C Skill 


\section{Pendahuluan}

Pada abad ke -21 ini, pendidikan memiliki peran penting untuk mencetak sumber daya manusia yang siap bersaing dengan negara lain. Peserta didik harus dilatihkan mengembangkan keterampilan berpikir 4C agar dapat bersaing di era ini. Penerapan keterampilan berpikir 4C ini akan memberikan manfaat yang besar bagi siswa dalam kehidupan sehari-hari (Rahmi, 2019). Keterampilan berpikir $4 \mathrm{C}$ terdiri dari keterampilan berpikir kritis dan problem solving, keterampilan berkomunikasi, berkolaborasi, serta berpikir kreatif dan inovatif. Untuk melatihkan pengembangan keterampilan berpikir 4C ini menjadi tentangan tersendiri bagi guru dikarenakan selama masa Pandemi Covid -19 ini, banyak sekali masalah yang dihadapi dalam dunia pendidikan.

Selama hampir dua tahun ini terhitung mulai tahun 2020 hingga kini, Pandemi Covid-19 masih setia melanda dunia. Bahkan mulai juli 2021 ini, Indonesia mulai menerapkan Pemberlakuan Pembatasan Kegiatan Masyarakat (PPKM). Kebijakan ini diambil karena adanya lonjakan kasus penderita Covid-19 yang sangat tinggi. Adanya PPKM tentunya mempengaruhi sektor pendidikan di Indonesia, yang sebelumnya telah memulai menerapkan Era New Normal dimana siswa sudah dapat kembali belajar secara tatap muka kini kembali dialihkan secara daring.

Selama pembelajaran daring, banyak sekali kendala yang dihadapi baik oleh siswa maupun pendidik (Chandra, 2021). Kendala yang sering kali dihadapi siswa adalah pembelajaran selalu berpusat pada guru selama pembelajaran daring yang mana diakbitkan oleh terbatasnya ruang interaksi antara siswa (Fauzy, 2021). Hal ini menyebabkan terbatasnya komunikasi antara siswa dan guru. Komunikasi yang terbatas antara siswa dan guru menyebabkan siswa kesulitan memahami materi (Huzaiman, 2021). Kesulitan yang dihdapi siswa tentunya memberikan dampak pada rendahnya hasil belajar siswa. Jika kuantitas dan kualitas pengetahuan peserta didik rendah maka tentunya hal ini akan berpengaruh terhadap keterampilan berpikir 4C peserta didik (Rahmi, 2019).
Oleh karena itu, diperlukan suatu pendekatan yang tepat agar dapat mengatasi kejenuhan siswa selam belajar daring dan tetap dapat melatihkan siswa untuk mengembangkan keterampilan berpikir 4C. Pembelajaran yang efisien dapat tercapai apabila menggunakan strategi, pendekatan, atau metode belajar yang tepat (Chandra,2016). Kemudian proses pembelajaran pada satuan pendidikan hendaknya diselenggarakan secara interaktif, inspiratif, menyenangkan, menantang, dan memotivasi untuk aktif (Adiastutty,2015).

Salah satu pendekatan yang dapat digunakan adalah Quantum Teaching and Learning (QTL). QTL dikembangkan berdasarkan asas "Bawalah Dunia Mereka ke Dunia Kita, dan Antarkan Dunia Kita ke Dunia Mereka" (DePorter,2010). Pernyataan ini memiliki arti bahwa hubungan antara guru dengan siswa harus saling mendukung (Chandra, 2021). Hal ini menunjukkan, betapa pengajaran dengan Quantum Teaching tidak hanya berfokus pada materi yang mesti dipelajari siswa. Tetapi jauh dari itu, siswa juga diajarkan bagaimana menciptakan hubungan emosional yang baik dalam dan ketika belajar (Chandra, 2021). Yang mana hal ini sulit dicapai selama pembelajaran daring. Guru memasuki dunia siswa yang dilakukan dengan mengaitkan secara langsung konsep-konsep yang akan dikaji dengan peristiwa sehari -hari atau dari pengalaman sehari-hari mereka. Dengan pengertian yang lebih luas dan mendalam berdasarkan interaksi tersebut, siswa akan dapat membawa apa yang mereka pelajari ke dalam dunia mereka, yakni sesuai bakat, minat, dan bidang keahliannya kemudian menerapkannya dalam situasi baru. Dengan menerapkan pembelajaran QTL diharapkan siswa akan lebih termotivasi dalam belajar karena apa yang disajikan sesuai dengan bakat dan minat siswa dan dapat meningkatkan interaksi antara siswa dengan guru (DePorter, 2010).

Selain itu untuk membuat siswa tetap dapat belajar secara aktif selam masa pembelajaran daring, maka akan diberikan tugas berbasis proyek yang dipadukan dengan pembelajaran QTL. Proyek yang 
ditugaskan pada siswa berupa penyelesaian masalah yang disajikan sesuai dengan bakat dan minat siswa. Proyek dalam bentuk seperti ini akan membuat siswa tidak bosan dengan pembelajaran yang sebelumnya hanya berpusat pada guru. Karena dalam penyelesaian proyek, siswa akan diminta untuk berkolaborasi dengan teman untuk mencari solusi dari masalah yang diberikan. Proyek yang diberikan akan mengacu pada Pembelajaran Berbasis Proyek (PjBL) dalam langkah-langkah penyelesaianya. $\mathrm{PjBL}$ dipilih karena pembelajaran berbasis proyek telah diamanahkan dalam Permenristekdikti no 44 tahun 2015 pada pasal 14.

PjBL adalah pembelajaran yang didasarkan pada tugas proyek berupa masalah dalam kehidupan sehari-hari yang harus diselesaikan oleh siswa (Anita, 2017). Penyelesaian proyek akan membuat pembelajarn terpusat pada siswa karena penyelesaian proyek menuntut siswa untuk mengkaji lebih jauh materi yang sedang dipelajari untuk menyelesaikan proyek yang diberikan. Penyelesaian proyek memberikan aktifitas belajar yang kompleks bagi siswa seperti berkolaborasi dengan teman kelompok, menganalisa, menyusun jadwal, menyelesaikan masalah, dan menyampaikan hasil proyek yang akan melatihkan siswa dalam pengembangan keterampilan berpikir 4C. PjBL diketahui mampu melatih untuk mengembangkan keterampilan berpikir 4C (Triana, 2020).

Selama masa pembelajaran daring diperlukan sebuah media yang dapat diakses dengan mudah oleh siswa. Dalam menciptakan harmonisasi dan dinamika pembelajaran yang kreatif dan interaktif, maka diperlukan peran Teknologi Informasi dan Komunikasi (TIK/ICT) sebagai instrumen teknologi pembelajaran interaktif, salah satu alat TIK yang dapat digunakan dalam pembelajaran adalah pembelajaran berbasis WEB (Yazdi, 2012). Dengan menggunakan media pembelajaran berbasis web, hal-hal dalam matematika yang cenderung abstrak dapat diperagakan secara visual, menggunakan animasi, dan simulasi, sehingga diharapkan siswa dapat secara aktif membangun komunikasi dan interaksi dengan materi pelajaran, dan ahirnya diharapkan prestasi semakin baik (Kumalasari, 2013).

Dalam tulisan ini akan dikaji bagaimanakah pembelajaran QTL berbasis proyek yang sesuai untuk dikembangkan dalam bentuk web agar dapat meningkatkan motivasi dan keterampilan berpikir $4 \mathrm{C}$ bagi siswa selama pembelajaran daring di masa Pandemi Covid 19 ini.

\section{Metode Penelitian}

Jenis penelitian ini yaitu penelitian deskriptif berbentuk studi literatur. Studi literatur dilakukan terhadap artikel-artikel yang membahas tentang pembelajaran Quantum Teaching and Learning (QTL), pembelajaran berbasis proyek (PjBL), pembelajaran berbasis WEB, dan keterampilan berpikir 4C siswa. Metode pengumpulan data yang digunakan dalam penelitian ini yaitu metode dokumentasi dengan instrumennya berupa hard ataupu soft file artikel. Kemudian untuk teknik analisis data yang digunakan mengadopso teori dari Miles dan Hulberman yang meliputi tahapan reduksi data, penyajian data, dan penarikan kesimpulan. Diagram alir dari studi literatur ini dapat dilihat pada Gambar 1. 


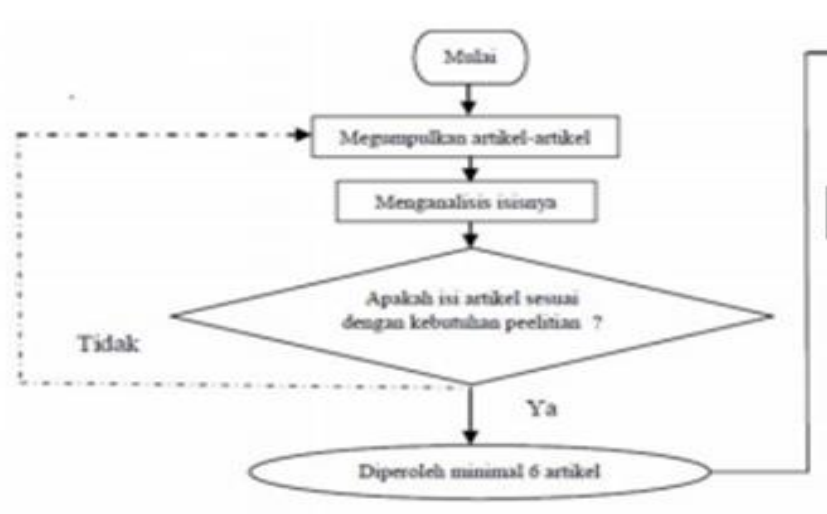

Gambar 1. Diagram Alir Prosedur Penelitian

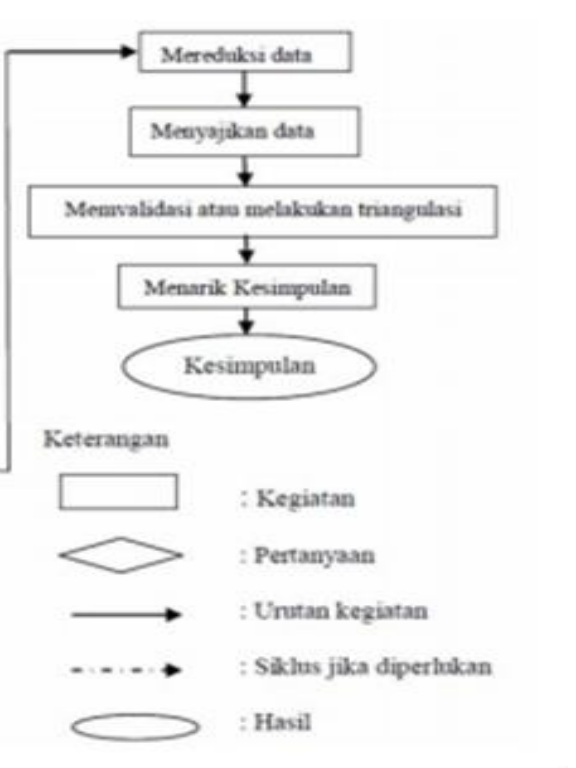

yang di dalamnya memiliki 6 tahap atau fase yaitu Tumbuhkan, Alami, Namai, Demonstrasikan, Ulangi, dan Rayakan (DePorter, 2010). Tumbuhkan berarti menumbuhkan minat belajar siswa dengan cara memberitahukan manfaat materi yang akan dipelajari. Alami berarti guru memberikan kesempatan siswa untuk memperoleh pengalamanpengalaman umum yang dapat dimengerti oleh mereka. Namai berarti guru menyediakan kata-kata kunci, konsep, rumus yang merupakan materi utama menjadi pesan pembelajaran. Demonstrasikan berarti guru menyediakan kesempatan bagi siswa dapat menunjukkan kemampuannya. Ulangi berarti guru menunjukkan kepada siswa cara mengulang materi dan menegaskan bahwa mereka benar-benar tahu akan apa yang dipelajari. Rayakan berarti guru memberikan pengakuan atas upaya yang telah dilakukan siswa dalam menampilkan penyelesaian, partisipasi, pemerolehan keterampilan, dan ilmu pengetahuannya.

Pembelajaran kuantum dibangun berdasarkan asas "Bawalah Dunia Mereka ke Dunia Kita, dan Antarkan Dunia Kita ke Dunia Mereka" (DePorter, 2010), memberikan pengertian bahwa hubungan antara guru dengan siswa harus saling mendukung. Guru memasuki dunia siswa sebagai upaya memperoleh ijin untuk memimpin, menuntun, dan memudahkan siswa untuk memahami ilmu pengetahuan. Upaya ini dilakukan antara lain dengan 
mengaitkan secara langsung konsep-konsep yang akan dikaji dengan peristiwa seharihari atau dari pengalaman sehari-hari mereka. Dengan pengertian yang lebih luas dan mendalam berdasarkan interaksi tersebut, siswa akan dapat membawa apa yang mereka pelajari ke dalam dunia mereka dan menerapkannya dalam situasi baru.

Menurut (DePorter, 2010) Quantum learning adalah seperangkat metode dan falsafah belajar yang terbukti efektif disekolah untuk semua tipe orang dan segala usia. Quantum learning ialah kiat, petunjuk, strategi, dan seluruh proses belajar yang dapat mempertajam pemahaman dan daya ingat, serta membuat belajar sebagai suatu proses menyenangkan dan bermanfaat.

Suatu proses pembelajaran akan menjadi efektif dan bermakna apabila siswa dapat belajar secara efektif, ada interaksi antara siswa dan sumber belajar dengan materi kondisi ruangan, fasilitas, penciptaan suasana dan kegiatan belajar yang tidak monoton diantaranya melalui penggunaan musik pengiring. Interaksi ini berupa keaktifan siswa dalam mengikuti proses belajar (Rahman, 2019). Menurut DePorter (2010) dengan belajar menggunakan Quantum learning akan didapatkan berbagai manfaat yaitu : bersikap positif, meningkatkan motivasi dan minat, keterampilan belajar seumur hidup , kepercayaan diri, dan sukses atau hasil belajar meningkat.

Dalam pembelajaran Quantum hal pertama yang diperlukan adalah membuat peserta didik mengetahu apa manfaat bagi mereka (AMBAK) dalam mempelajari suatu materi (DePorter, 2010). Hal ini akan mampu membuat peserta didik mengerti manfaat apa yang didapatkan dari mempelajari suatu materi, karena sebelum belajar siswa harus mengetahui AMBAK dari pelajaran yang dipelajari. Dengan mengetahui AMBAK tersebut siswa mempunyai tujuan yang pasti dalam melakukan pembelajaran.Sehingga dapat membuat siswa bersikap positif dalam melakukan pembelajaran.

Penelitian yang dilakukan oleh (Rahman, 2019) menyatakan bahwa pembelajaran QTL mampu meningkatkan kemampuan berpikir kreaktif siswa. Kemudin (Iskandar, 2017) menyatakan PjBL merupakan model pembelajaran yang melatih peserta didik untuk memecahkan masalah sehari-hari baik secara individua atau kelompok yang disajikan dalam bentuk proyek yang harus diselesaikan peserta didik dalam pembelajaran. (Wicaksana, 2017) juga menjelaskan bahwa PjBL merupakan pembelajaran yang dirancang untuk digunakan pada permasalahan kompleks dalam kehidupan sehari-hari yang memerlukan investigasi siswa untuk memahaminya. (Anjarsari, 2017) menjelaskan bahwa PjBL merupakan model pembelajaran inovatif yang kontekstual dan memberikan pengalaman belajar lebih menarik dan bermakna bagi siswa.

Dari definisi-definisi di atas, dapat disimpulkan bahwa PjBL merupakan model pembelajaran yang melatih peserta didik untuk menyelesaikan permaslahan dalam kehidupan sehari-hari yang lebih kompleks dan kontekstual dalam bentuk proyek, sehingga dapat memberikan pengalaman belajar yang lebih menarik dan bermakna bagi peserta didik.

Langkah-langkah $\mathrm{PjBL}$ menurut Hosnan \& Sikumbang (Azizah, 2019) secara umum langkah-langkah kegiatan pembelajaran berbasis proyek yaitu: (1) penentuan proyek; (2) perancangan langkah-langkah penyelesaian proyek; (3) penyusunan jadwal pelaksanaan proyek; (4) penyelesaian proyek dengan fasilitasi dan monitoring guru; (5) penyusunan laporan dan presentasi/ publikasi hasil proyek; (6) evaluasi proyek dan hasil proyek.

Penelitian yang dilakukan oleh (Rahman, 2019) menyatakan bahwa pembelajaran QTL mampu meningkatkan kemampuan berpikir kreaktif siswa. Penelitian yang dilakukan oleh (Nurhikmayati, 2020) mendapatkan hasil Model PjBL efektif terhadap kemampuan berpikir kreatif dan berpengaruh positif terhadap kemandirian belajar. Penelitian yang dilakukan oleh (Prabowo, 2012) menyatakan bahwa PJBL mampu meningkatkan pemahaman.

Dalam Pembelajaran QTL berbasis proyek, langkah-langkah pembelajaran 
PjBL akan dintegrasikan dalam AMBAK dan kerangka QTL yakni TANDUR. Masalah yang disajikan dalam $\mathrm{PjBL}$ akan dijadikan sebagai kekuatan AMBAK (manfaat) bagi siswa untuk mempelajari materi. Ketika siswa memahami kekuatan AMBAK dari materi yang akan dipelajari maka pembelajaran akan menjadi lebih bermakna. Selanjutnya, langkah penyelesaian masalah yang dintegrasikan dalam bentuk proyek akan diterapkan dalam kerangka QTL. Pada fase tanamkan, siswa akan dijelaskan AMBAK dari materi dan dihubungkan dengan masalah yang berkaitan dengan materi. Pada fase alami, siswa akan diminta mengerjakan proyek dalam bentuk penyelesaian masalah. Namai berarti siswa akan menuliskan kata-kata kunci, konsep, rumus yang merupakan materi utama yang menjadi pesan pembelajaran dan akan dijadikan rancangan langkah-langkah penyelesaian proyek. Demonstrasikan berarti guru memberikan kesempatan pada peserta didik untuk menyelesaikan proyek sesuai rancangan penyelesaian yang telah dibuat. Ulangi berarti siswa diminta mempresentasikan hasil pengerjaan proyek dengan menyampaikan presentasi hasil proyek yang dilakukan sebagai bentuk pengulangan dan penguatan terhadap materi yang dipelajari. Rayakan berarti guru memberikan pengakuan atas upaya yang telah dilakukan siswa dalam menampilkan penyelesaian, partisipasi, pemerolehan keterampilan, dan ilmu pengetahuannya.

Selanjutnya pendekatan QTL berbasis proyek ini akan dituangkan dalam bentuk WEB. Hal ini dilakukan agar selama pembelajaran daring, siswa tetap dapat aktif belajar. WEB yang dibuat harus disesuaikan dengan bakat dan minat siswa. Pembelajaran berbasis web merupakan suatu kegiatan pembelajaran yang memanfaatkan media situs (website) yang bisa di akses melalui jaringan internet
(Rahman,2019). Pembelajaran berbasis WEB menurut (Rusman,2012), memeliki beberapa kelebihan diantaranya yaitu: Access is available anytime, anywhere, around the globe (akses tersedia kapanpun, dimana pun, di seluruh dunia), Perstudent equipment costs are affordable (biaya operasional setiap siswa untuk mengikuti kegiatan pembelajaran enjadi lebih terjangkau), Student tracking is made easy (pengawasan terhadap perkembanga siswa jadi lebih mudah), Possible "learning object" architecture supports on demand personalized learning (rancangan pembelajaran berbasis web memungkinkan dilakukannya kegiatan pembelajaran yang sudah terpersonalisasi), Contentisealy update (materi pembelajaran bisa diperbarui secara lebih mudah).

Web pembelajaran QTL berbasis proyek akan berisi materi yang dibuat bertemakan bakat dan minat siswa. Pada dari tampilan cover, background, dan content yang berupa ilustrasi materi, contoh soal, dan aplikasi sesuai bakat dan minat siswa. Sehingga diharapkan dapatkan membangkitkan suasana belajar yang menyenangkan bagi siswa. Materi pada web pembelajaran QTL berbasis proyek juga akan dilengkapi efek audio sehingga akan membuat kegiatan pembelajaran menjadi tidak membosankan karena melibatkan indra pendengar. Proyek yang disajikan juga berupa video yang langsung berkaitan dengan masalah yang biasa dihadapi siswa dalam kehidupan seharihari.

Dari kegiatan pembelajaran daring yang menggunakan Web pembelajaran QTL berbasis proyek diharapkan mampu meningkatkan motivasi dan keterampilan berpikir 4C siswa. Keterampilan berpikir 4C meliputi berpikir kritis dan Problem solving, keterampilan berkomunikasi, berkolaborasi, serta berpikir kreatif dan inovatif (Rahmi, 2019). 


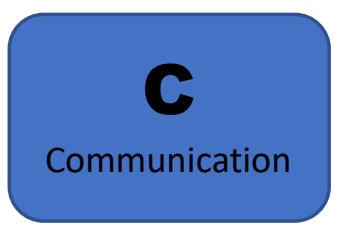

Berbagi informasi, ide, dan solusi dari sebuah masalah secara lisan maupun tulisan

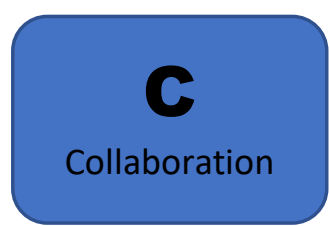

Bekerja bersama untuk mencapai sebuah tujuan

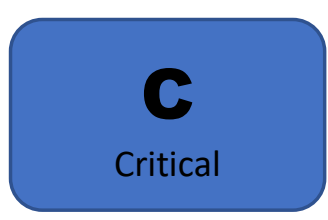

Menghubungkan materi dengan masalah kontekstual atau melihat masalah dengan cara yang baru

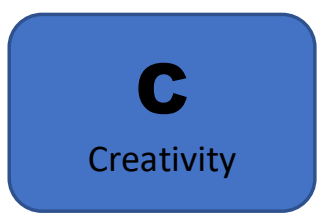

Mencoba

pendekatan baru, mencari sesuatu ide baru yang yang lebih inovatif

\section{Gambar 2. Rasional Keterampilan Berpikir 4C}

Keterampilan berpikir kritis merupakan cara berpikir reflektif dan beralasan yang difokuskan pada pengambilan keputusan untuk memecahkan masalah dengan mencoba ide baru yang lebih invovatif. Dalam pembelajaran QTL berbasis proyek akan melatihkan siswa untuk memiliki keterampilan berpikir kritis. Dalam tahap Tanamkan melalui menjelaskan AMBAK dari materi yang dipelajari siswa, maka siswa akan belajar menghubungkan materi yang akan dipelajari dengan masalah kontekstual yang ada dalam kehidupan sehari-hari. Keterampilan berpikir krritis merupakan keterampilan menemukan hal baru ayng belum ada sebelumnya seperti mengembangkan berbagai solusi baru untuk menyelesaikan masalah (Leen, 2014). Dalam pembelajaran QTL berbasis proyek siswa akan dilatihkan berpikir kreaktif dan inovatif dalam menyelesaikan masalah yang diberikan dalam bentuk proyek dalam fase alami. Siswa akan dilatihkan untuk berpikir kreaktif dalam merancang penyelesaian masalah. Keterampilan komunikasi merupakan kegiatan menyampaikan informasi baik secara lisan maupun tulisan (Simanjuntak, 2019). Pada pembelajaran QTL berbasis proyek tepatnya pada kegiatan mendemostrasikan ulangi siswa akan berlatih mengkomunikasikan gagasan yang merupakan penyelesaian dari proyek yang diberikan. Kolaborasi adalah penggunaan keterampilan komunikatif untuk mencapai tujuan bersama, bekerja secara produktif dengan yang lain, saling bersinergi, menghormati orang lain, dan kerja sama tim sambil menghasilkan ide bersama (Kemendikbud, 2013). Dalam pembelajaran QTL berbasis proyek, siswa akan diminta menyelesaikan proyek secara berkelompok untuk melatihkan keterampilan berkolaborasi siswa.

Penelitian yang dilakukan oleh (Rahman, 2019) menyatakan bahwa pembelajaran QTL mampu meningkatkan kemampuan berpikir kreaktif siswa. Penelitian yang dilakukan oleh (Nurhikmayati, 2020) mendapatkan hasil Model PJBL efektif untuk menigkatkan kemampuan berpikir kreatif dan berpengaruh positif terhadap kemandirian belajar. Penelitian yang dilakukan oleh (Prabowo, 2012) menyatakan bahwa PjBL mampu meningkatkan pemahaman siswa. Penelitian yang dilakukan oleh (Triana, 2020) menyatakan bahwa pembelajaran STEM-PjBL dapat meningkatkan keterampilan berpikir 4C siswa. (Leen,2014) juga menyatakan bahwa PjBL dapat meningkatkan keterampilan berpikir 4C siswa. Penelitian yang dilakukan oleh (Maielfi, 2020) menyatakan bahwa Pembelajaran Quantum Teaching tipe TANDUR dapat meningkatkan kemapuan kolaborasi siswa yang merupakan salah satu dari kemampuan berpikir 4C.

Berdasarkan kajian artikel-artikel terkait Pembelajan QTL, Pembelajaran $\mathrm{PjBL}$, pembelajaran berbasis WEB, dan keterampilan berpikir 4C maka dapat disimpulkan bahwa pembelajaran QTL 
berbasis proyek dalam bentuk web dapat meningkatkan keterampilan berpikir 4C.

\section{Simpulan dan Saran}

Berdasarkan hasil penelitian studi literatur yang telah dilakukan maka kesimpulan yang dapat diambil adalah pembelajaran QTL berbasis proyek dalam bentuk web dapat meningkatkan keterampilan berpikir 4C siswa. Pembelajaran berbasis proyek yang dintegrasikan dalam pembelajaran QTL akan melatihkan siswa mengembangkan keterampilan berpikir 4C dan menambah motivasi belajar siswa selama pembelajaran daring, karena QTL akan menjadikan pembelajaran disajikan sesuai bakat dan minat siswa yang dihubungkan dengan masalah-masalah kontekstual dalam kehidupan sehari-hari. Pembelajaran QTL berbasis proyek yang dapat dilaksanakan untuk meningkatkan motivasi dan keterampilan 4C siswa dapat dibuat dengan langkah-langkah pembelajaran $\mathrm{PjBL}$ yang dintegrasikan dalam AMBAK dan kerangka QTL yakni TANDUR. Masalah yang disajikan dalam PjBL akan dijadikan sebagai kekuatan AMBAK (manfaat) bagi siswa untuk mempelajari materi. Ketika siswa memahami kekuatan AMBAK dari materi yang akan dipelajari maka pembelajaran akan menjadi lebih bermakna. Selanjutnya, langkah penyelesaian masalah yang dintegrasikan dalam bentuk proyek akan diterapkan dalam kerangka QTL yang akan melatihkan siswa untuk dapat mengembangkan keterampilan berpikir 4C. Pendekatan QTL berbasis proyek ini akan dituangkan dalam bentuk WEB agar selama pembelajaran daring, siswa tetap dapat aktif belajar.

\section{Daftar Pustaka}

Anita, Ika. (2017). Implementasi Pembelajaran Berbasis Proyek Untuk Menumbuhkan Kemampuan Berpikir Kreatif Matematis Mahasiswa. JPPM Vol. 10 No. 1

Adiastuty, N. (2015). Tahapan Pembelajaran Matematika SMK yang Mengarah pada Pemecahan Masalah (POLYA). Jurnal Euclid .Prodi
Pendidikan Matematika Uswagati Cirebon Vol 2. No. 2.

Ajarsari, E. (2017). Pengembangan Perangkat Pembelajaran Bangun Ruang Sisi Data Berbasi Project Based learning (PjBL) untuk Mengembangkan Kecerdasan Spasial. Tesis: Universitas Jember

Azizah, I dan Widjayanti, D. (2019). Keefektifan pembelajaran berbasis proyek ditinjau dari prestasi belajar, kemampuan berpikir kritis, dan kepercayaan diri siswa. Jurnal Riset Pendidikan Matematika Vol.6 No.2

Chandra, F. (2016) . Pengaruh Problem Possing Berbantuan Mind Mapping terhadap Kemampuan Pemecahan Masalah dan Penalaran Ditinjau dari Gaya Kognitif. Jurnal AXIOMA Jurnal Pendidikan Universitas Islam Jember. Vol. 1 No. 1.

Chandra, F \& Rahman, S. (2021). Pengembangan Perangkat Pembelajaran Matematika Model Quantum Teaching and Learning Berbasis Web Materi Geometri Transformasi pada Siswa SMK di Era New Normal. Jurnal Deltha Phi, Vol. 10, No. 1.

DePorter, B. dan Hernacki, M. (2010). Quantum Teaching and Learning. Bandung: Kaifa

Fauzy, A \& Nurfauziyah, P. (2021). Kesulitan Pembelajaran Daring Matematika pada Masa Pandemi COVID-19 di SMP Muslimin Cililin. Jurnal Cendekia: Jurnal Pendidikan Matematika, Vol. 05, No. 01.

Huzaimah, P dan Amelia, R. (2021). Hambatan yang Dialami Siswa Dalam Pembelajaran Daring Matematika Pada Masa Pandemi COVID-19. Jurnal Cendekia: Jurnal Pendidikan Matematika. Vol. 5 No 1. 
Iskandar dan Raditya. (2017). Pengembangan Bahan Ajar Project Based Learning Berbantuan Scratch. Seminar Nasional Matematika dan Aplikasinya, 21 Oktober 2017 Surabaya, Universitas Airlangga

Kumalasari, Elisia. (2013). Pembelajaran Matematika Dengai\{ Gaided Insuiry Berbasis Web Ditinjau Dari Mottvasi Belajar Siswa. Prosiding Seminar Nasional Pendiditan don SAINS Program Studi Pendidikan Maemaika FKIP Universitas Jember, Maret 2013.

Leen, C.C., Hong, H., Kwan, F.F.H. \& Ying, T.W. (2014). Creative and Critical Thinking in Singapore Schools. Singapore: National Institute of Education, Nanyang Technological University.

Maielfi, D. dan Wahyuni, S. (2020). Model Quantum Teaching Tipe Tandur Terhadap Keterampilan Kolaborasi Mahasiswa. JIPI (Jurnal IPA dan Pembelajaran IPA), Vol. 4, No.2.

Nurhikmayati dan Sunendar. (2020). Pengembangan Project Based Learning Berbasis Kearifan Lokal Berorientasi pada Kemampuan Berpikir Kreatif dan Kemandirian Belajar. Mosharafa: Jurnal Pendidikan Matematika Vol.9 No.1.

Prabowo, A. (2012). Pembelajaran Berbasis Proyek Untuk Meningkatkan Pemahaman Mahasiswa atas Permasalahan Statistika pada Perkuliahan Studi Kasus dan Semina. JURNAL KREANO. Vol. 3 No. 2.
Rahmi, A dan Suparman. (2019). Analisis Kebutuhan Modul dengan Pendekatan CTL untuk Meningkatkan Motivasi Belajar dan Keterampilan 4c pada Peserta Didik. Prosiding Sendika: Vol 5, No 1

Rahman, S. (2019). Pengembangan Perangkat Pembelajaran Matematika Model Quantum Teaching And Learning Berbasis Web Guna Meningkatkan Kemampuan Berfikir Kreatif Siswa SMK. Tesis: Universitas Jember

Rusman. (2012). Model-model Pembelajaran. Jakarta: PT Raja Grafido Persada

Simanjuntak, M., dkk. (2019). Desain pembelajaran berbasis proyek terhadap 4C. Jurnal Inpafi Vol. 7 No.3

Triana, D. dkk. (2020). Effectiveness of Environmental Change Learning Tools Based on STEM-PjBL Towards 4C Skills of Students. Journal of Innovative Science Education. Vol. 9 No. 2.

Wicaksana, dkk. (2017). Analisis Kemampuan Literasi Matematika dan Karakter Rasa Ingin Tahu Siswa pada Pembelajaran Berbasis Proyek Berbantuan Schoolog. UJMER Vol. 6 No. 2

Yazdi, M. (2012). E-Learning Sebagai Media Pembelajaran Interaktif Berbasis Teknologi Informasi. Jurnal Ilmiah Foristek. Sulawesi Tengah: Fakultas Matematika dan Ilmu Pengetahuan Alam Universitas Tadulako 